as this month has seen the centenary of Sachs' birth. In commemoration of this event, two former pupils of Sachs, Dr. D. H. Scott and Prof. F. O. Bower, delivered approciatory addresses and gave some personal reminisoences of the great plant physiologist. Another former student in Sachs' laboratory, Prof. S. H. Vines, was unfortunately prevented by ill-health from being present but in a written address, which was read at the meoting, he dealt more particularly with the stimulus which Sachs' "Lehrbuch der Botanik" gave to the development of botany in Great Britain. There can be no doubt that, distinguished as he was for his contributions to plant physiology, Sachs was a great all-round botanist and an inspiring teacher, whose influence through the raany pupils he attracted to his laboratory from all countries was felt wherever botany was studied.

\section{Industrial Depression and Gold Reserves}

A LECruRe by Dr. H. Levinstein on "World Problems of the Chemical Industry" at the Imperial College of Science and Technology on October 27 formed the first of a series of addresses in which men who have won distinction in various fields will present views on industrial affairs to students of the College. Taking the ratio of external trade to popula. tion as a measure of the standard of living of a community, Dr. Levinstein showed that more than half the world has a standard which is very much below that of Europe, although the latter is itself far from luxurious. Modem industry has been built up on the assumption that people can be persuaded to buy things which their forefathers did without, and there is no reason for believing that industrial expansion is approaching a limit. The recent set. back in the development of worlci trade, which started with the fall in prices of primary commodities, thereby reducing the purchasing power of the agricultural community and eventually of the whole population, is, in Dr. Levinstein's opinion, a temporary condition brought about mainly by abnormal shifting of gold reserves. There is no actual shortage of available gold deposits. The trouble is due to the removal of gold from where it can perform its proper service to industry. Although the State took charge of the production of munitions during the War, it made no attempt to meet the gold payments demanded by the United States by undertaking extraction of the metal from ore, although this might have been done by working deposits of lower grade than private companies would exploit. Actually, the gold required was taken from reserves and a collapse of trade followed. It was as if a demand to be paid in bricks was met by pulling down houses.

\section{Progressive Chemical Industry}

Although gold production is of great importance to industry, as was shown years ago by the effects of the introduction of the cyanide process, Dr. Levinstein said that the humen factor is always of vital signif. eance in any consideration of industrial problems.
Political economists are apt to forget that men do not always behave in a manner best suited to the furtherance of their economic interests, but are often influenced by foar and prejudice. Science alone builds continuously upon the work of previous investigators, and has a unique record of pro gressive development. To young men now entering the chemical industry it may seem that opportunities for making profitable discoveries and improvements are becoming less numerous, but Dr. Levinstein said he had heard such views expressed thirty years ago and considers them as false to-day as they were then. There is certainly great scope for fresh ideas and discoveries in the dye-stuff industry, and he believes that the fine chemical industry as a whole offers extensive opportunities to young chemists. Finally, further advances in biochemistry may be expected to open up vast new fields for chemists to explore. Indeed, more precise knowledge of the factors governing the growth of the living cell will undoubtedly lead to great developroents in medicine.

\section{The Aircraft Industry and Chemical Engineering}

Tre value of research in chemical engineering formed the substance of the first Hinchley memorial lecture delivered before the Institution of Chemical Engineers by Mr. H. T. Tizard on October 28. At first sight the aircraft industry seems very remote from the chemical industry, but developments in aeronautics have already been of great value to the chemical industry. Perhaps the most striking exarnple of this may be found in the development of cellulose paints. The possible uses of solutions of nitrocellulose and cellulose acetate were explored on a small scale before the War, but they were first used on the large scale for the protection of the fabric of aeroplanes and balloons. During the War scientific knowledge of cellulose esters accumulated rapidly, and the manufacture of cellulose acetate was begun. The shortage of the usual solvents forced upon us the necessity of trying substitutes, so enlarging our knowledge of cellulosed solutions and preparing the way for the economic production of modern cellulose firishes. The manufacture of cellulose esters and solvents is now one of the most important branches of chemical industry.

Tase strong incentive to obtain the highest thermal efficiency in aircraft engines has led to the manufacture and use of lead tetra-ethyl on a large scale. There is now an equally strong incentive to develop heavy oil internal combustion engines for aircraft. It is quite possible that this will only be satisfactorily accomplished if a suitable synthetic chemical com pound can be found to promote the smooth com bustion of oil when injected into the engine cylinder. Again, the economic suecess of air transport depends largely on the working life of an engine between overhauls, and this depends mainly on the stability of lubricating oil. The study of lubricants becomes more and more a chemical problem and in future

No. 3288, VoL. 130] 